\title{
HIV RISK BEHAVIOR AND WORK IN UGANDA: A CROSS-SECTIONAL STUDY
}

\author{
Esther Buregyeya ${ }^{1,2,3} *$, William Bazeyo ${ }^{1,}$ Bente E. Moen ${ }^{3}$ Charles Michelo ${ }^{4}$, Knut Fylkesnes ${ }^{2}$
}

\begin{abstract}
Objective: The study assessed the prevalence of factors associated with HIV risky behaviour among employees of a Sugar Factory in Jinja District, Uganda.

Methods: A cross-sectional study of 321 participants was carried out in a Sugar Factory where several workers were migrants. Using an interviewer-administered questionnaire, information on socio-demographic characteristics, work factors and sexual behaviours was obtained.

Results: Fifty-one percent of the men and $32 \%$ of the women reported having multiple sex partners in the past year. Thirty-six percent of the respondents reported using condoms during the last casual sex. Twenty-four percent of men and $15 \%$ women reported sexually transmitted infection-related symptoms in the last one-year. Having multiple sex partners was associated with being a contract worker $(\mathrm{OR}=\mathbf{2 . 1}, \mathbf{9 5} \% \mathrm{CI}=\mathbf{1 . 1 0 - 3 . 7 9})$ and being married but not living with spouse $(\mathrm{OR}=2.1,95 \% \mathrm{CI}=1.16-4.00)$.

Conclusion: HIV risk behaviour among Sugar Factory workers is associated with separation from partner. HIV intervention strategies should include work related factors of this type.
\end{abstract}

Keywords: HIV, Sexual, Risk behaviour, Factory, Workplace, Uganda

\section{Introduction}

In sub-Saharan Africa, the HIV epidemic has continued to be a major developmental problem that has broken down the social and economical systems $(1,2)$. In the workplaces the main negative effects are reduced production, depleted human capital, increasing the number of AIDS orphans and increasing child labour which in turn remain a major challenge to social security systems $(1,2)$. In addition, it has brought about discrimination in employment, social exclusion of people living with HIV and increased gender inequalities (2).

Globally, the age group worst affected by the epidemic is the 15-49 years old. This is the most productive age category, whose contributions to the family, society and the national economy are being lost. The International Labour Organization (ILO) estimates that at least 26 million people infected with HIV worldwide are workers in this age group, contributing over $70 \%$ of all adults living with HIV (2). It is further estimated that the workforce in the high prevalence countries will be reduced by $10-30 \%$ by the year 2020 due to HIV. It is projected that Uganda will have lost $16 \%$ of its workforce, Zimbabwe $19 \%$ and Botswana $17 \%$ (2). Unless prevention efforts are intensified and targeted, HIV infection will continue to ravage the work force, making huge negative impacts in society.

There is evidence that some occupational groups, for example migrant workers and truck drivers, are more vulnerable in acquiring the HIV infection than others (24). The reason for their increased vulnerability is suggested to

Correspondence to: Esther Buregyeya' Makerere University School of Public Health, P.O. Box 7072 Kampala- Uganda,

${ }^{1}$ Department of Disease Control and Environmental Health, Makerere University School of Public Health, P.O. Box 7072 Kampala- Uganda, Telephone: 256-752420555, Fax: 256-41-531807 E-mail: eburegyeya@musph.ac.ug

${ }^{2}$ Centre for International Health, Amauer Hansen Building, University of Bergen, Norway. Email: Knut.Fylkesnes@ cih.uib.no

${ }^{3}$ Department of Public Health and Primary Health Care, Section for Occupationa Health, University of Bergen-Norway. E-mail: bente.moen $@$ isf.uib.no

${ }^{4}$ Department of Community Medicine, University of Zambia School of Medicine, Lusaka, Zambia. E-mail: cmichelo@zambia.co.zm be due to work-related factors; particularly mobility and seasonal migration (2,5-7).

The main underlying factor may be the social disruption caused by the migration of young men without their partners, causing skewed sex ratios $(2,5)$. This in turn is associated with other proximate determinants of HIV infection $(6,8)$.

In Uganda, factors associated with HIV infection among workers have not been fully examined. Doing so is critical in order to monitor and evaluate relevancy of current prevention efforts in general. The aim of the present study was to assess factors indicating HIV risky behaviour among employees at a sugar factory in Jinja District, Uganda, where there were workers migrating from the districts nearby. We also wanted to study the relation between the occurrence of HIV risk factors and work related factors. It is envisaged that correct information about sexual risk behaviour is critical in designing appropriate strategies to prevent and control HIV/AIDS in the workplace.

\section{Material and Methods}

A cross-sectional study was conducted at Kakira Sugar Works located in a peri-urban setting of Jinja District, Uganda. The study site was chosen as it is a common destination for migrant men from northern and eastern part of the country (rural areas) and also attracts labour force from the nearby districts. Thus there are two types of migration prevalent in this workplace: long distance migration with infrequent trips home and short distance migration with more frequent trips home.

The factory is involved in the production of sugar and sweets and houses both schools (primary and secondary schools) and a company hospital. The entire sugar estate covers approximately 7,935 hectares of land. The company currently employs about 6,300 workers of which about 4,000 are contract workers and 2,300 are permanent employees. This workplace is male dominated, with females accounting for only 5\% of the total workforce. The females are employed in the company hospital, 
schools, administration and a few in the field as weeders. The majority $(60 \%)$ of the workforce, are contract workers and working in the field as cane cutters, weeders and cane transporters. The rest, work in the factory where they do bagging, loading and cleaning.

The contract workers are usually employed on shortterm basis; 1-2 years, usually housed in camps (single sex camps) and not allowed to bring their spouses/families along. The permanent category of workers is mainly in administration, factory and security. There is a trading center close to the factory where retail commercial services and bars are, and these are the main social gathering places for the local population (especially commercial sex workers) and factory workers. The company has an HIV/AIDS prevention programme, where they carry out Counseling and Testing for HIV, health education about HIV/AIDS and provision of free condoms to all workers. In addition management of sexually transmitted infections (STI) is carried out, according to the Uganda Ministry of Health guidelines.

\section{Study participants}

Data were collected between August and September 2003. Before the study started, a sample size calculation was based on assumptions of a prevalence of reported high-risk sex for adults of $28 \%$ (9) and a significance level of 0.05 . The required sample size was calculated to 309 participants (10). In addition, 12 more participants were added, as refusals and incomplete questionnaires were expected, giving a total of 321 participants needed. Inclusion criteria for the participants were to be African employees of the Sugar Factory, involved in sugar production, i.e. cutting, weeding and transportation of the cane, and the processing into sugar. Six out of the total 27 camps were randomly selected. Workers in camps were interviewed after returning from work and every one found in the camp and who consented was interviewed. The nonfield category of workers, i.e. those employed in the administration and factory, were interviewed either during lunch break or after work (after 17.00hrs).

\section{Interview}

A semi-structured questionnaire with a few openended questions was used to interview the workers. We collected data on socio-demographic characteristics and workplace information; age, education level, marital status, terms of employment (permanent/contract), living with family at the workplace, living arrangements at the workplace (single or mixed sex), how long since they last saw their family/partner, length of employment, work category (field/non field) and salary earned per month. In addition to this, respondents were also asked about their sexual behaviours and history of STIs during the past year; the number of sex partners, use of condoms and history of genital ulcer or urethral discharge and swelling in the groin. There were three interviewers, and they underwent two days of intensive training prior to field activities. Interviews were carried out in privacy.

\section{Data analysis}

Data were coded and entered into the computer using Epi-Info version 6 (Centers for Disease Control and Prevention epiinfo@cdc.gov) and the analysis was done using SPSS Window version 11.5 (SPSS Inc. Chicago Illinois). Men and women were analyzed separately. Tests of significance for categorical variables were performed by Chi-squared tests, or Fisher's exact test for variables below five. Multiple logistic regression was used to analyze factors that were independently associated with HIV risk behaviour. Crude and adjusted odds ratios were calculated as well as $95 \%$ confidence intervals. There were small numbers of women in the different strata, limiting the possibility of doing regression analyses. Because of this only descriptive data is given for the females.

\section{Ethical clearance}

Ethical clearance was obtained from the Regional Committee for Medical Research Ethics in Western Norway and the Uganda National Council of Science and Technology through the Institute of Public Health at Makerere University in Uganda. Permission from the factory administration was granted. Verbal informed consent was obtained from each of the respondents.

\section{Results}

\section{Description of participants}

Of the total of 321 workers who were interviewed, $252(78.5 \%)$ were males and $69(21.5 \%)$ females. The mean age for males was 31.1 years and females were found to be slightly older with a mean age of 33.8 years. The majority of the respondents were married, $71 \%$ of the males and $61 \%$ of the females. About half of the workers who were married reported not living with their partners at the workplace. The majority of the respondents had attained secondary level of education, with $48 \%$ of the males and $29 \%$ of the females. A higher proportion of women compared to men had no formal education, with $20 \%$ versus $8 \%$ respectively. Women were found to have worked at the factory longer than men, with a median working length of 6 years and 3 years, respectively. Fifty three percent of the men worked in the field and $60 \%$ were employed on contract terms, while $20 \%$ of the women worked in the field, and $44 \%$ were employed on contract terms. Only two respondents refused to be interviewed (Table 1).

\section{Multiple sex partners}

Thirty two percent of the women reported sex with two or more partners (Table 2). More educated female respondents had lesser chances of reporting multiple sex partners, with proportion of $45 \%, 25 \%$ and $17 \%$, for primary or less, secondary and tertiary levels of education, respectively. Half of the men reported having had sex with two or more sex partners in the last one-year (Table 2). 
Table1: Socio-demographic and work characteristics among employees of a sugar factory, participating in a study of HIV risk behaviour

\begin{tabular}{|c|c|c|}
\hline Sex & Males $(n=252)$ & Females $(n=69)$ \\
\hline Age (mean/SD) & $31.1(7.63)$ & $33.8(7.08)$ \\
\hline \multicolumn{3}{|l|}{ Marital status (no/\%) } \\
\hline Married & $179(71 \%)$ & $42(61 \%)$ \\
\hline Others ('single') & $73(29 \%)$ & $27(39 \%)$ \\
\hline \multicolumn{3}{|l|}{ Length of employment } \\
\hline Mean (years) & 4.95 & 7.91 \\
\hline Median (years) & 3.00 & 6.33 \\
\hline \multicolumn{3}{|l|}{ Educational level (no/\%) } \\
\hline$<$ Primary & $20(8 \%)$ & $14(20 \%)$ \\
\hline Primary & $75(30 \%)$ & $17(25 \%)$ \\
\hline Secondary & $121(48 \%)$ & $20(29 \%)$ \\
\hline Tertiary & $36(14 \%)$ & $18(26 \%)$ \\
\hline \multicolumn{3}{|l|}{ Work category (no/\%) } \\
\hline Field & $133(53 \%)$ & $14(20 \%)$ \\
\hline Non field & $119(47 \%)$ & $55(80 \%)$ \\
\hline \multicolumn{3}{|l|}{ Type of accommodation (no/\%) } \\
\hline Single male sex camp & $108(43 \%)$ & \\
\hline Mixed sex arrangement & $144(57 \%)$ & $69(100 \%)$ \\
\hline \multicolumn{3}{|l|}{ Salary (no/\%) } \\
\hline$<25$ USD & $217(86 \%)$ & $45(65 \%)$ \\
\hline$\geq 25$ USD & $35(14 \%)$ & $24(35 \%)$ \\
\hline \multicolumn{3}{|l|}{ Employment status (no/\%) } \\
\hline Permanent & $100(40 \%)$ & $39(57 \%)$ \\
\hline Contract & $152(60 \%)$ & $30(44 \%)$ \\
\hline \multicolumn{2}{|l|}{ Married \& living with family } & $24 / 42(57 \%)$ \\
\hline Yes & $91 / 179(51 \%)$ & $18 / 42(43 \%)$ \\
\hline No & & \\
\hline
\end{tabular}

Table 2. HIV risk behaviour among male and female employees of a sugar factory

\begin{tabular}{|c|c|c|}
\hline Indicator & $\begin{array}{l}\text { Males no } \\
(\%)\end{array}$ & $\begin{array}{l}\text { Females no } \\
(\%)\end{array}$ \\
\hline $\begin{array}{l}\text { Multiple sex partners } \\
(\text { males } n=252 \text {, females } n=69)\end{array}$ & $128(51)$ & $22(32)$ \\
\hline \multicolumn{3}{|l|}{ Condom protection } \\
\hline $\begin{array}{l}\text { Ever used a condom } \\
\text { (males } n=242, \text { females } n=68)\end{array}$ & $144(60)$ & $32(47)$ \\
\hline $\begin{array}{l}\text { Condom use at last casual sex } \\
(\text { males } n=131 \text {, females } n=22 \text { ) }\end{array}$ & $47(36)$ & $8(36)$ \\
\hline $\begin{array}{l}\text { Reported STIs }{ }^{2} \\
(\text { males } n=252, \text { females } n=69)\end{array}$ & $61(24)$ & $10(15)$ \\
\hline
\end{tabular}

Younger male respondents (less than 30 years) were more likely than the older ones to report this, with a proportion of $55 \%$ and $47 \%$, respectively, (Table 3 ). The proportion of respondents reporting having casual sex was higher among respondents with low levels of education than the respondents with higher levels of education. There were no differences among the single and married men with this regard.

In a multiple logistic regression analysis; adjusting for age, level of education and marital status, contract work $(\mathrm{OR}=2.195 \% \mathrm{CI}=1.10-3.79)$ and being married but not living with family ( $\mathrm{OR}=2.195 \% \quad \mathrm{CI}=1.16-4.00)$ were found to be significant risk factors for having multiple sex partners among the men (Table 3). There was no difference by age, by dividing the workers into two age groups, below and above 30 years.

Table 3: Factors associated with multiple sex partners among male employees employed at a sugar factory, using a multiple logistic regression analysis

\begin{tabular}{|c|c|c|c|c|}
\hline $\begin{array}{l}\text { Socio-demographic and } \\
\text { work factors }\end{array}$ & $\mathbf{n}$ & $\%$ & $\begin{array}{l}\text { Crude OR } \\
(95 \% \mathrm{CI})\end{array}$ & $\begin{array}{c}\text { Adjusted } \\
\text { OR }(95 \% \mathrm{CI}) *\end{array}$ \\
\hline \multicolumn{5}{|l|}{ Age groups } \\
\hline$<\mathbf{3 0}$ years & $63 / 114$ & 55 & $1.4(0.84-2.28)$ & \\
\hline$\geq 30$ years & $65 / 138$ & 47 & 1 & \\
\hline \multicolumn{5}{|l|}{ Level of education } \\
\hline$\leq$ Primary & $49 / 95$ & 52 & $2.0(0.86-4.15)$ & \\
\hline$\overline{\text { Secondary }}$ & $66 / 121$ & 55 & $2.1(1.00-4.58)$ & \\
\hline Tertiary & $13 / 36$ & 36 & 1 & \\
\hline \multicolumn{5}{|l|}{ Marital status } \\
\hline Single & $38 / 73$ & 52 & $1.1(0.62-1.85)$ & \\
\hline Married & $90 / 179$ & 50 & 1 & \\
\hline \multicolumn{5}{|l|}{ Terms of employment } \\
\hline Contract & $88 / 152$ & & $2.1(1.23-3.45)$ & $2.1(1.10-3.79)$ \\
\hline Permanent & $40 / 100$ & & - & 1 \\
\hline \multicolumn{5}{|l|}{ Living with family } \\
\hline No & $54 / 91$ & & $1(1.16-3.83)$ & $2.1(1.16-4.00)$ \\
\hline Yes & $36 / 88$ & & 1 & 1 \\
\hline \multicolumn{5}{|l|}{ Time taken to visit family } \\
\hline$\leq 3$ months & $25 / 49$ & & $0.5(0.22-1.18)$ & $0.5(0.19-1.16)$ \\
\hline$\geq 4$ months & $29 / 43$ & & (2) & 1 \\
\hline \multicolumn{5}{|l|}{ Work category } \\
\hline Field & $77 / 140$ & & $1.5(0.89-2.41)$ & $1.3(0.78-2.25)$ \\
\hline Non-field & $51 / 112$ & & 1 & 1 \\
\hline \multicolumn{5}{|l|}{ Type of accommodation } \\
\hline Single sex & $59 / 108$ & & $1.3(0.79-2.16)$ & $1.2(0.67-2.01)$ \\
\hline Mixed sex & $69 / 144$ & & 1 & 1 \\
\hline
\end{tabular}

*Adjusted for age, education level and marital status

\section{Condom use at last casual sex}

Thirty six percent of the males, who reported casual sex, reported using a condom the last time they were involved in casual sex (Table 2). Younger males, less than 30 years were more likely than older ones to report this ( $51 \%$ versus $21 \%$, respectively).However, single men were more likely than the married ones to report use of condoms during casual sex (Table 4). There was no difference in the proportion of this behaviour across the different levels of education. Similarly, $36 \%$ of females who reported having multiple sex partners, had used condoms on the last casual sex. Like males, the younger females below 30 years were more likely than older ones to report use of condoms during casual sex, $71 \%$ versus $20 \%$, respectively. Like among the men, there were no differences in the proportions of this behaviour across the different levels of education. In a regression analysis among male participants, the factor that was significantly associated with condom use during the last casual sex, was age, with an $\mathrm{OR}=4.0,95 \% \mathrm{CI}=1.80-8.769$ and marital status $(\mathrm{OR}=2.6,95 \% \mathrm{CI}=1.18-5.80)$ (Table 4). 
Table 4: Factors associated with condom use at last casual sex among male employees of a sugar factory, using multiple logistic regression analysis

\begin{tabular}{|c|c|c|c|c|}
\hline $\begin{array}{l}\text { Socio-demographic and } \\
\text { work factors }\end{array}$ & n & $\%$ & $\begin{array}{c}\text { Crude } \\
\text { OR }(95 \% \mathrm{CI})\end{array}$ & $\begin{array}{c}\text { Adjusted } \\
\text { OR } \\
(95 \% \mathrm{CI}) *\end{array}$ \\
\hline \multicolumn{5}{|l|}{ Age } \\
\hline$<30$ years & $31 / 61$ & 51 & $4.0(1.80-8.76)$ & \\
\hline$\geq 30$ years & $13 / 63$ & 21 & 1 & \\
\hline \multicolumn{5}{|l|}{ Level of education } \\
\hline$\leq$ Primary & $17 / 47$ & 36 & $1.3(0.34-4.77)$ & \\
\hline Secondary & $23 / 64$ & 36 & $1.3(0.35-4.56)$ & \\
\hline Tertiary & $4 / 13$ & 31 & 1 & \\
\hline \multicolumn{5}{|l|}{ Marital status } \\
\hline Single & $19 / 37$ & 51 & $2.6(1.18-5.80)$ & \\
\hline Married & $25 / 87$ & 29 & 1 & \\
\hline \multicolumn{5}{|l|}{ Terms of employment } \\
\hline \multirow{2}{*}{$\begin{array}{l}\text { Contract } \\
\text { Permanent }\end{array}$} & $34 / 84$ & 41 & $2.0(0.89-4.72)$ & $1.6(0.55-4.63)$ \\
\hline & $10 / 40$ & 25 & 1 & 1 \\
\hline \multicolumn{5}{|l|}{ Living with family } \\
\hline No & $16 / 51$ & 31 & $1.4(0.53-3.58)$ & $1.3(0.46-3.62)$ \\
\hline Yes & $9 / 36$ & 25 & 1 & 1 \\
\hline \multicolumn{5}{|l|}{ Work category } \\
\hline Field & $27 / 73$ & 37 & $1.2(0.55-2.50)$ & $1.1(0.512 .56)$ \\
\hline Non-field & $17 / 51$ & 33 & 1 & 1 \\
\hline \multicolumn{5}{|l|}{ Type of accommodation } \\
\hline Mixed sex & $21 / 55$ & 38 & $1.2(0.60-2.60)$ & $1.4(0.60-3.18)$ \\
\hline & $23 / 69$ & 33 & 1 & 1 \\
\hline
\end{tabular}

*Adjusted for age, level of education and marital status.

\section{Self reported STIs}

The overall prevalence of reported STIs among the men was $24 \%$ (Table 2). There were no significant differences between age groups (Table 5). STIs were reported less often in the highly educated men, compared to those with lower levels of education (34\% compared to $8 \%$ ). Married men were more likely than the single ones to report STIs, with a proportion of $26 \%$ versus $21 \%$, respectively.

Among the females, there was an overall prevalence of STIs of $15 \%$ (Table 2). Women, below 30 years were more likely than the older ones to report having had STIs, $30 \%(6 / 20)$ versus $8 \%(4 / 49)$, respectively. The proportion of reported STIs decreased with increase in the level of education, among females. An equal proportion of married and single women, $14 \%$ and $15 \%$, respectively reported STIs in the past one year. After adjusting for age, education and marital status among men, being married and not living with partner/family at the workplace was found to be associated with reported STIs in the last 12 months $(\mathrm{OR}=2.6 ; 95 \% \mathrm{CI}=1.23-5.30)$, Table 5. Low level of education was also an independent risk factor for reported STIs among men, $\mathrm{OR}=5.6,95 \% \mathrm{CI}=1.60-19.62$.
Table 5. Prevalence of self reported STIs and associated factors among male employees of a sugar factory by using multiple regression analyses

\begin{tabular}{|c|c|c|c|c|}
\hline $\begin{array}{l}\text { Socio-demographic \& } \\
\text { work factors }\end{array}$ & No/n & $\%$ & $\begin{array}{c}\text { Crude } \\
\text { OR }(95 \% \mathrm{CI})\end{array}$ & $\begin{array}{c}\text { Adjusted } \\
\text { OR (95\%CI) } \\
* \\
\end{array}$ \\
\hline $\begin{array}{l}\text { Age } \\
\leq 30 \text { years } \\
>30 \text { years }\end{array}$ & $\begin{array}{l}31 / 114 \\
30 / 138\end{array}$ & $\begin{array}{l}27 \\
22\end{array}$ & $\begin{array}{c}1.3(0.76-2.40) \\
1\end{array}$ & \\
\hline $\begin{array}{l}\text { Level of education } \\
\text { <Primary } \\
\text { Secondary } \\
\text { Tertiary }\end{array}$ & $\begin{array}{c}32 / 95 \\
26 / 121 \\
3 / 36\end{array}$ & $\begin{array}{c}34 \\
22 \\
8\end{array}$ & $\begin{array}{c}5.6(1.60-19.62) \\
3.0(0.86-10.60) \\
1\end{array}$ & \\
\hline $\begin{array}{l}\text { Marital status } \\
\text { Single } \\
\text { Married }\end{array}$ & $\begin{array}{c}15 / 73 \\
46 / 179\end{array}$ & $\begin{array}{l}21 \\
26\end{array}$ & $\begin{array}{c}0.7(0.40-1.45) \\
1\end{array}$ & \\
\hline $\begin{array}{l}\text { Terms of employment } \\
\text { Contract } \\
\text { Permanent }\end{array}$ & $\begin{array}{l}45 / 152 \\
16 / 100\end{array}$ & $\begin{array}{l}30 \\
16\end{array}$ & $\begin{array}{c}2.2(1.17-4.18) \\
1\end{array}$ & $\begin{array}{c}1.6(0.76-3.38) \\
1\end{array}$ \\
\hline $\begin{array}{l}\text { Living with family } \\
\text { No } \\
\text { Yes }\end{array}$ & $\begin{array}{l}32 / 91 \\
14 / 88\end{array}$ & $\begin{array}{l}35 \\
16\end{array}$ & $\begin{array}{c}2.9(1.40-5.86) \\
1\end{array}$ & $\begin{array}{c}2.6(1.23-5.30) \\
1\end{array}$ \\
\hline $\begin{array}{l}\text { Type of accommodatio } \\
\text { Single sex } \\
\text { Mixed sex }\end{array}$ & $\begin{array}{l}32 / 108 \\
29 / 144\end{array}$ & $\begin{array}{l}30 \\
20\end{array}$ & $\begin{array}{c}1.7(0.94-3.00) \\
1\end{array}$ & $\begin{array}{c}1.2(0.66-2.31) \\
1\end{array}$ \\
\hline $\begin{array}{l}\text { Work category } \\
\text { Field } \\
\text { Non-field }\end{array}$ & $\begin{array}{l}42 / 140 \\
19 / 112\end{array}$ & $\begin{array}{l}30 \\
17\end{array}$ & $\begin{array}{c}2.1(1.14-3.87) \\
1\end{array}$ & $\begin{array}{c}1.6(0.86-3.10) \\
1\end{array}$ \\
\hline
\end{tabular}

\section{Discussion}

This study examined the prevalence of HIV risk behaviour and how work-related factors were associated with this behaviour among employees of a sugar factory in Uganda. HIV risk behaviours were found in this workforce as indicated by multiple sex partners, low condom use and self reported symptoms of STIs. This type of sexual behaviour was associated with work-related factors, particularly being a contract worker and being married but not residing with regular sex partner. This indicated that the increased HIV risk behaviour in such occupational groups can be clearly related to the work situation, as the relation to the partner is disturbed.

The proportion reporting multiple partners in the past year in our study, is far above the level found in the general population in Uganda. According to the data from the Uganda Demographic and Health Survey (UDHS) $2000 / 01$ (11), $28 \%$ of the males and $14 \%$ of the females reported having sex with non-marital and non-cohabiting partners. As our study group is older than in this statistics which includes only the age group 15-49 years, the figures are difficult to compare directly. However, the proportion of reported multiple sex partners tended to be highest in the youngest age group and among those with lowest levels of education in our study. This suggests that core prevention messages may not have reached this group. The findings are consistent with a study of trucking company workers in Kenya, where young age was a risk factor for acquiring HIV (8).

Despite the high proportion of respondents reporting multiple sex partners in our study, we found a relatively low proportion of condom use in both men and women. This indicates that HIV incidence among these workers might be relatively high, as these are well known risk 
factors for HIV transmission (12). We also noted a high proportion of self-reported STI related symptoms, which also is a probable sign of a low and inconsistent condom use, particularly during casual relationships. Reported STIs were also found to be associated with work-related factors and being married but not living with partner. These findings of high proportion of casual sex and high prevalence of self reported STIs among respondents not living with partner support each other. Furthermore, STI symptoms tended to be more prevalent among respondents with lower levels of education as compared to higher education levels. This creates a special risk group with lower education which can pose limitations in prevention efforts (13-14).

Our findings on risk behaviours are consistent with previous studies, where men who live away from their wives are more likely than those who live with their wives to have multiple sex partners (5) and to be infected with STIs $(5,14)$. A study conducted among male factory workers in Zimbabwe (15), found that men residing separately from their wives were more likely to report multiple sexual partners and having STIs than men residing with their wives. Other studies $(6,8)$ have shown that men who live away from their wives or regular partners are more likely to have additional partners and therefore more likely to become infected with STIs. This is likely to be an effect of mobility, causing family disruption and increasing the chances of these employees to engage in higher risk sex. A study on migration and HIV-1 seroprevalence in a rural Ugandan community, found that individuals who migrated had more sexual partners than those remaining in the same area (16).

The findings from the present study are probably not particularly related to the type of work, but to the work situation, affecting families and sexual behaviour. However, a previous study has been performed among women in a sugarcane factory in the Dominican Republic. The study showed that migrating women from Haiti were more likely to have HIV infection, and a very low condom use was reported among these workers (17). This supports the findings of our present study.

In our study, only workers who were found in their camps after work were included in the study. Because of this, there is a possibility of a selection bias on these in our results. However, this could have been an underestimated problem, as most of the workers who were not in their camps could have gone to drink alcohol which is a known risk factor for HIV risk behaviour. Also, the selection of informants was not systematic, as those available and willing to be interviewed were included. They were not randomly selected from a list of workers. It is difficult to know if this method led to an underestimation of the problems or not. We chose not to diagnose HIV among the workers studied, but to use an interview to obtain the information. This makes our registrations less objective. However, the interviewers were instructed in the same manner to perform the interviews as objective as possible, and in privacy. As the findings were quite similar to several other studies in this area, the method seems to be adequate, and might be recommended for further studies.

The present findings ought to have implications for the design of HIV/AIDS control programmes for workplaces and work policies. It is particularly interesting that these findings were observed in Uganda, where the prevalence of HIV-infection has been clearly reduced in the past years, although stable in the most recent years. This probably means that the work groups discussed here are at higher risks than the population in general, and need more focused preventive programs. Intervention programmes on work places often are inefficient and improvement in this area is needed (18). The occupational pattern of sexual behaviors observed in the current study indicates that employment conditions are associated with HIV risk behaviour, and that more information is needed. Migrating workers also ought to be provided with accommodation for their families/partners.

\section{Conclusion}

We conclude that there is high prevalence of HIV risk behaviour compared to the general population in this workplace and that work factors seem to be associated with this behavior. The family separation in this workplace was found to be a standing policy as contract workers were not allowed to stay with their families/partners. This calls for a policy shift in the design of HIV/AIDS control programmes for workplaces and work policies. Intervention strategies should include work-related policies and factors that increase the likelihood of HIV transmission.

\section{Competing interests}

The authors declare that they have no competing interests.

\section{Acknowledgements}

We acknowledge financial support from the Norwegian government through NORAD for funding the study. We also thank the management of the Sugar Factory for the opportunity to carry out this study in their workplace and for the material support they provided. Special thanks go the respondents and other employees of the Sugar Factory for freely participating in the study. We also wish to appreciate the contribution of the research assistants, namely: Osembo Martin and Walter Okumu for their diligent work and for whom without their input this work would have been even harder.

\section{References}

1. World Health Organisation. HIV/AIDS Report by the secretariat at the $54^{\text {th }}$ World Health Assembly. Geneva: WHO, $9^{\text {th }}$ April 2001.

2. Franklyn L. Labour market and employment implications of HIV/AIDS. ILO programme on HIV/AIDS and the World of Work Geneva, 2002.

3. Uniting the world against AIDS (UNAIDS) and World Health Organisation. AIDS epidemic update. Geneva: Joint UN programme on HIV/AIDS, No CPO78, December 2002.

4. Uniting the world against AIDS (UNAIDS). Report on the global HIV/AIDS epidemic. Geneva: Joint UN Programme on HIV/AIDS, 2002.

5. Kumwenda N, Taha ET, Hoover DR, Markakis D, Liomba G, Chiphangwi JD et al. Three surveys of HIV-1 prevalence and risk factors among men working at a sugar estate in Malawi. Sex Transm Dis 2002; 29:366-71.

6. Lurie MN, Williams BG, Zuma K, Zuma K, Mkaya-mwamburi D, Garnett GP et al. The impact of migration on HIV-1 transmission in South Africa: a study of migrant and non migrant men and their partners. Sex Transm Dis 2003; 30:149-56.

7. Ramjee G and Gouws E. Prevalence of HIV among truck drivers visiting sex workers in Kwa-Zulu-Natal, South Africa. Sex Transm Dis 2002; 29:44-9. 
8. Rakwar J, Lavreys L, Thompson ML et al. Cofactors for the acquisition of HIV-1 among heterosexual men: prospective cohort study of trucking company workers in Kenya. AIDS 1999; 13:607-14.

9. Uniting the world against AIDS (UNAIDS) Uganda epidemiological fact sheet on HIV/AIDS and Sexually Transmitted Infections. Geneva: UNAIDS, 2002.

10. Kish, L(ed). Survey Sampling. New York, NY: John Wiley \& Sons, Inc, 1965.

11. Uganda Bureau of Statistics, Uganda demographic and health survey 20002001. Calverton, Maryland, USA, 2001, pages183-184.

12. Bassett MT, McFarland WC, Rays S, Mbizvo MT, et al. Risk factors for HIV Infection at enrolment in an urban male factory cohort in Harare, Zimbabwe. J.AIDS 1996; 13:287-293.

13. Michelo C, Sandoy I F and Fylkesnes K. Marked HIV prevalence declines in higher educated young people: evidence from population-based surveys (19952003) in Zambia. AIDS 2006, 20(7):1031-1031.
14. Serwadda D, Musgrave DS, Sewankambo NK, et al. HIV risk factors in three geographic strata of rural Rakai district, Uganda. AIDS 1992; 6:983-9.

15. Mbizvo MT, Machekano R, McFarland W, Ray S, Basset M, Latif A, et al: HIV seroincidence and correlates of seroconversion in a cohort of male factory workers in Harare, Zimbabwe. AIDS 1996; 10:895-901.

16. Nunn AJ, Wagner H, Kamali A. Migration and HIV-1 seroprevalence in a rural Ugandan population. AIDS 1995, 9:503-506.

17. Brewer T, Hasbun J, Ryan C et al. Migration, ethnicity and environment: HIV risk factors for women on the sugar cane plantations of the Dominican risk factors for women on the sugar
Republic. AIDS 1998; 12:1879-1887.

18. Wilson MG, Jorgensen C, Cole G. The health effects of worksite HIV/AIDS interventions: A review of the research literature. Sci Health Promotion 1996; 11:150-157

Received 20 September 2007; Revised 20 January 2008; Accepted 28 January 2008 